\title{
Variants of Specific Surfaces in the Bakoven Member: Union Springs Formation of the Marcellus Subgroup in Central New York State (USA)
}

\author{
Fosu-Duah Evelyn Love ${ }^{1 \star}$, Eswaran Padmanabhan ${ }^{1}$, D. Jeffery Overs ${ }^{2}$ and Jose Antonio Gamez Vintaned ${ }^{1}$ \\ ${ }^{\prime}$ Department of Geosciences, University of Technology Petronas, Malaysia \\ ${ }^{2}$ State University of New York, Geneseo, USA
}

\section{Article Info}

\section{*Corresponding author: Fosu-Duah Evelyn Love \\ Department of Geosciences University of Technology Petronas Malaysia \\ E-mail: love.duah@gmail.com}

Received: November 26, 2018

Accepted: December 10, 2018

Published: December 17, 2018

Citation: Evelyn Love FD, Padmanabhan E, Over DJ, Gamez Vintaned JA. Variants of Specific Surfaces in the Bakoven Member: Union Springs Formation of the Marcellus Subgroup in Central New York State (USA). Int J Petrochem Res. 2018; 2(3): 230-235.

doi: $10.18689 / \mathrm{jjpr}-1000140$

Copyright: ๑ 2018 The Author(s). This work is licensed under a Creative Commons Attribution 4.0 International License, which permits unrestricted use, distribution, and reproduction in any medium, provided the original work is properly cited.

Published by Madridge Publishers

\begin{abstract}
The variants of specific surfaces of 40 samples from the Bakoven Member of the Union Springs formation have been studied using physicochemical methods.

Variations in the specific surface areas were attributed to differences in the quantities of clay minerals as well as organic matter content and types. The 2:1 clay minerals like illite and smectite were the main contributors of specific surface areas due to their large intracrystalline surfaces. Low external surface areas reported in some samples might be due to either the competition of adsorptive sites for nitrogen molecules with organic matter or the organic matter blocking of some adsorptive sites and micropores on the sample surface. The opposite is true for most of the samples that reported high TOC values suggesting that organic matter might have provided additional sorption sites for the polar compound but further study is needed to clarify. An excellent positive relationship between surface area and total organic carbon suggested that most organic matter in the samples are adsorbed.
\end{abstract}

Keywords: Clays; Organic matter; Specific Surface Area; Micropores

\section{Introduction}

Specific surface area (SSA) (expressed in squared meters $/ \mathrm{gram}\left(\mathrm{m}^{2} / \mathrm{g}\right)$.) is used in literature to refer to the area per unit mass of sample [1,2]. It is known to greatly influence various chemical and physical properties of rocks. Physisorption, heat loss or gain resulting from such adsorption, swelling and shrinking are closely related to SSA $[3,4]$. It has been shown that SSA correlates remarkably with important properties such as exchangeable cations/anions and water retention. For instance, $\mathrm{Na}$-saturated clay fractions from a sample have surface area values that are 40\% lesser than the same fraction when Ca- saturated. Aside cation exchange capacity (CEC), SSA may be the dominant factor in controlling the fundamental behaviors of shales [5]. The specific surface area in shale differs remarkably as a result of differences in texture, mineralogy, particle size distribution and organic matter (OM) content $[3,6]$.

This implies that not every part of the surface of a sample contributes to important geological processes such as adsorption and ion exchange. Fine-grained particles particularly the layered silicates are the main contributors of the inorganic surface areas in rocks [2]. Nonexpanding clays like kaolinites and some micas have only external surfaces ranging from $10-70 \mathrm{~m}^{2} / \mathrm{g}$ [7] while phyllosilicates like smectite have large internal as well as external surfaces giving SSA up to $810 \mathrm{~m}^{2} / \mathrm{g}$, depending upon the amount of internal surface exposed by expansion. Consequently, the types of clay minerals in a shale largely determine their SSA and related properties. 
Clay minerals contribute the greatest amount to surface area of mineral constituents of a sample, but are likely to also differ greatly deal in SSA. Clay mineral constituents are thus the determining factor in SSA on rock properties because of their platy habit and because some clays have large intracrystalline surface areas (ISA) [8-10].

SSA can be considered an intrinsic property controlled by grain size distribution and clay mineralogy [2]. It is a constant related to sample constituents and does not vary by external properties such as water content, time and location [11]. SSA helps determine the accessibility of the internal surfaces of clay mineral-complexes to molecules or ions which can be adsorbed [3].

SSA is known as the single most contributing factor for gas adsorption in unconventional systems (e.g., shale gas). For example, numerous studies have shown a positive correlation between SSA and OM $[2,5,12]$. As petroleum and/or gas are sourced from $\mathrm{OM}$, the erudition of the factors that play significant roles in their preservation is indispensable to the industry. This study is therefore aimed at investigating the variations of specific surfaces as a function of mineralogy, organic carbon richness and aromaticity in the Bakoven Member of the Union Springs Formation.

\section{Study Area}

\section{Location}

The Marcellus Subgroup is located in the Appalachian basin across six states including Pennsylvania, New York, West Virginia, Maryland, and Ohio (Figure 1). It covers a total area of approximately 100,000 square miles and the depth at which its bottom is located ranges from of 1200 to 2600 meters with an average thickness of about 20 to 80 meters. The shale contains largely untapped natural gas reserves, and its propinquity to the high-demand markets in the United States making it an attractive target for energy development and export [13].

\section{Tectonics}

The Paleozoic history of the Appalachian basin consists of three orogenic events induced by collisions between the North American plates (Laurentia) and the eastern oceanic crust, converting the region from a passive margin during the Ordovician to a foreland basin and a narrow seaway [14]. At various times, the basin was the site of restricted circulation and accumulation of organic-rich units (e.g., Utica-Point Pleasant and Marcellus subgroup). The Acadian Orogeny, beginning in the Middle Devonian, resulted in subsidence near the Acadian mountains and uplift on the opposite side caused by flexural deformation [15].

During the Middle and Late Devonian, the Appalachian foreland basin was bounded by the developing Acadian mountains on the east and south, the Cincinnati arch on the west, and the Old Red Sandstone continent to the north, and it was connected to the Rheic Ocean by a long and narrow seaway in the southwest, forming a nearly enclosed epicontinental sea $[16,17]$. Tectonic loading stemming from this event coupled with eustatic sea level rise terminated shallow-shelf carbonate deposition during the Devonian and led to the accumulation of several organic-rich shale units, including the Marcellus subgroup.

\section{Stratigraphy}

The Union Springs Formation comprises all strata between the upper Onondaga Limestone and the base of the HurleyCherry Valley Limestone in Western New York [18].

The lower contact between the Upper Onondaga Limestone and the Union Springs Formation has been defined as a regional unconformity in the eastern sector of the Appalachian basin and amalgamated with the Walbridge unconformity in the northeastern portion of it, but it is conformable in New York [19]. The Union Springs Formation comprises of two laterally gradational units: the Bakoven Member in the west and the Stony Hollow Member [20] in the east of New York State. Although the Bakoven Member used to be restricted to the black fissile shale in the east, it now embodies all the entire black shale facies of the Union Springs Formation including those in central and western New York. The Stony Hollow Member is composed of calcareous shale and fine sandstone facies that underlie the Hurley Member of the Oatka Creek Formation. The type locality is in Union Springs, Cayuga County, NY in Wood's Quarry (Figure 1).

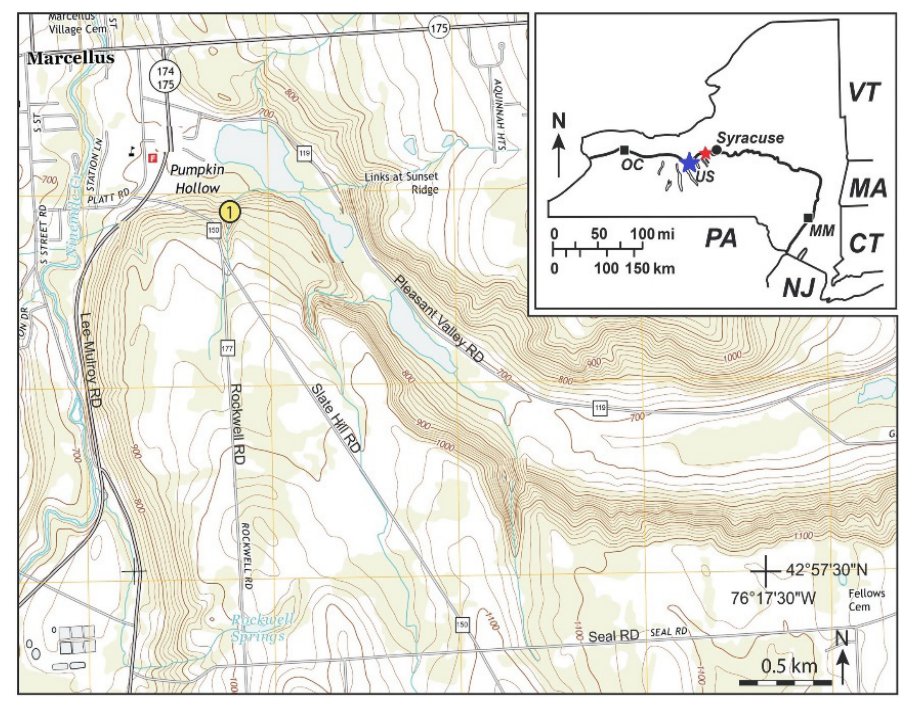

Figure 1. Map showing sample location (1) in "Firehouse Creek," black and blue stars mark the location of Marcellus, NY and the type localities of the Union Springs Formation in Union Springs, NY, respectively (Modified after [21]).

\section{Materials and Methods}

\section{Materials}

Powders of forty (40) samples; labeled SM01 to SM20 and then SQ01 to SQ20 from the Bakoven Member of the Union Springs Formation at Firehouse Creek-Marcellus Township and Seneca stone quarry (New York State) respectively have been used for the study presented here.

\section{Mineralogical Analysis}

Mineralogical compositions were derived from X-ray diffraction (XRD) patterns measured on randomly oriented 
powders. Analyses were performed on the fine fraction (< $20 \mu \mathrm{m}$ ) from representative shale samples of uniform crystallite sizes achieved through milling with a Fristch-Pulveristte 2 mill and subsequent clay separation using procedures detailed by Conptom and Allison [22], Suryanarayana and Norton [23] and Klug and Alexander [24]. Diffractograms were recorded in the $2 \theta$ in the range of $3^{\circ}-60^{\circ}$ with a scan speed of $1^{\circ} 20 / \mathrm{mm}$. All reported mineral compositions relate to the crystalline content of the analyzed samples $[25,26]$. Mineral morphologies were determined and confirmed by the use of Field Emission Scanning Electron Microscopy (FESEM) and Electron Diffraction Spectroscopy (EDS).

\section{Specific Surface Areas}

External Surface Area (XSA) of sample particles were determined by single point nitrogen adsorption [27] using a Micromeritics ASAP 2020 instrument. The samples were outgassed for 24 hours at $80^{\circ} \mathrm{C}$ prior to measurements. Total Surface Areas (TSA) were determined by the ethylene glycol monoethyl ether (EGME) method described by $[3,12,28]$. The differences between TSA and XSA were recorded as the Internal Surface Area (ISA) [2].

\section{Total Organic Carbon (TOC) Analysis}

TOC was determined on powdered samples with a Multiwinanalyticjena (Multi N/C 3100) TOC/TNb analyzer adopting the direct method proposed by Dow and Pearson [29]. About $60 \mathrm{mg}$ of pulverized whole rock sample pretreated with $0.1 \mathrm{M}$ hydrochloric acid to remove inorganic carbon (carbonates) was used for the analysis. The residual materials were used for the determination of TOC by combustion analysis of temperatures in excess of $850^{\circ} \mathrm{C}$. The evolved gas (CO) was measured quantitatively and simultaneously by infrared detectors and recorded as the percentage of carbon. TOC is reported on a dry weight basis [29].

\section{Ultraviolet-visible (UV-VIS) Spectroscopy}

UV-vis spectroscopy was performed on dichloromethane extracted hydrocarbon using a Shimadzu UV-3150 spectrophotometer adopting procedures described in Schnitzer and Neyroud [30], Stevenson [31], and then Ramli and Padmanabhan [32]. The primary interest for this analysis was to determine the ratios of aromatic (E4) to aliphatic (E6) hydrocarbon components at the wavelengths of $465 \mathrm{~nm}$ and $665 \mathrm{~nm}$ respectively.

\section{Fourier Transform Infrared Spectroscopy (FTIR)}

FTIR was achieved on an Agilent Technologies Cary 660 Series FTIR Spectrometer. Samples of $2 \mathrm{mg}$ and $0.5 \mathrm{mg}$ were dispersed in PIKE MIRACLE diamond attenuated total reflectance spectroscopy (ATR) to record optimal spectra in the regions of $4000 \mathrm{~cm}^{-1}$ to $500 \mathrm{~cm}^{-1}$ with a resolution of 4 $\mathrm{cm}^{-1}$ and 64 scans. Spectral manipulation such as baseline adjustment and smoothing was performed using a Spectrocalc software package (Galactic Industries Corporation, NH, USA). Interested functional groups identified in results are based on standards in [33] and [34] shown in (Figures 3 and 4).

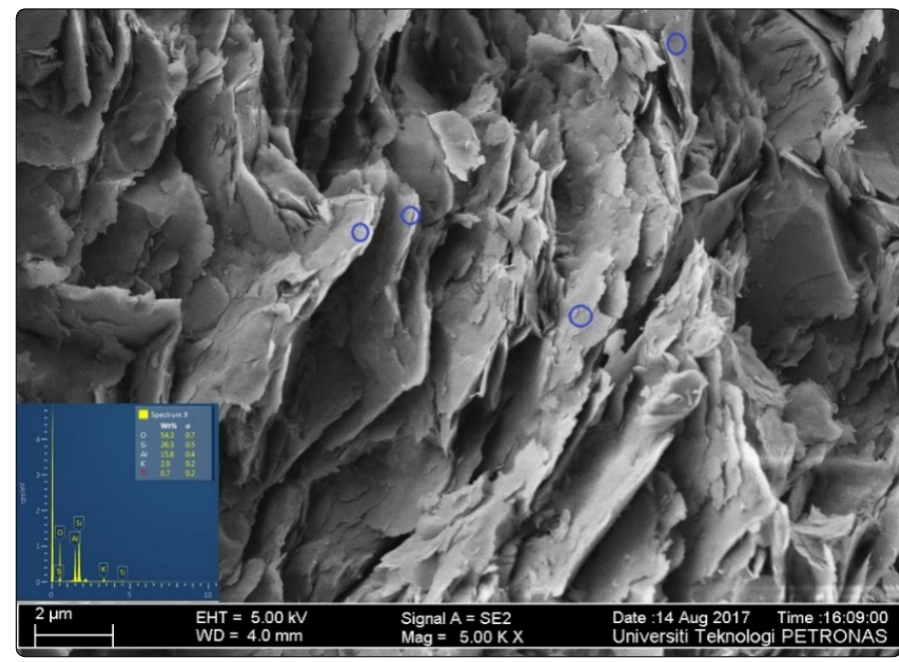

Figure 3. FESEM micrographs of Kaolinite with EDS

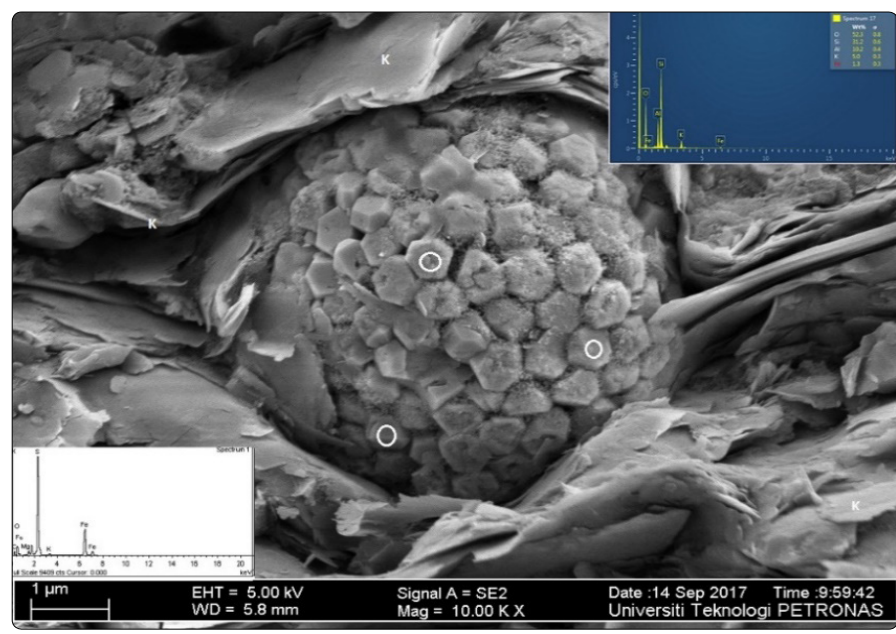

Figure 4. FESEM micrographs showing (O) of Pyrite and (K) Illite with their respective EDS spectrum.

\section{Results and Discussion}

\section{Marcellus: Firehouse Creek}

The bulk mineralogical composition of samples from this locality are fairly homogenous with quartz, illite, pyrite and kaolinite as the commonest minerals. Slight differences are the presence of calcite, dolomite, and aragonite in a couple of samples (Figure 2).

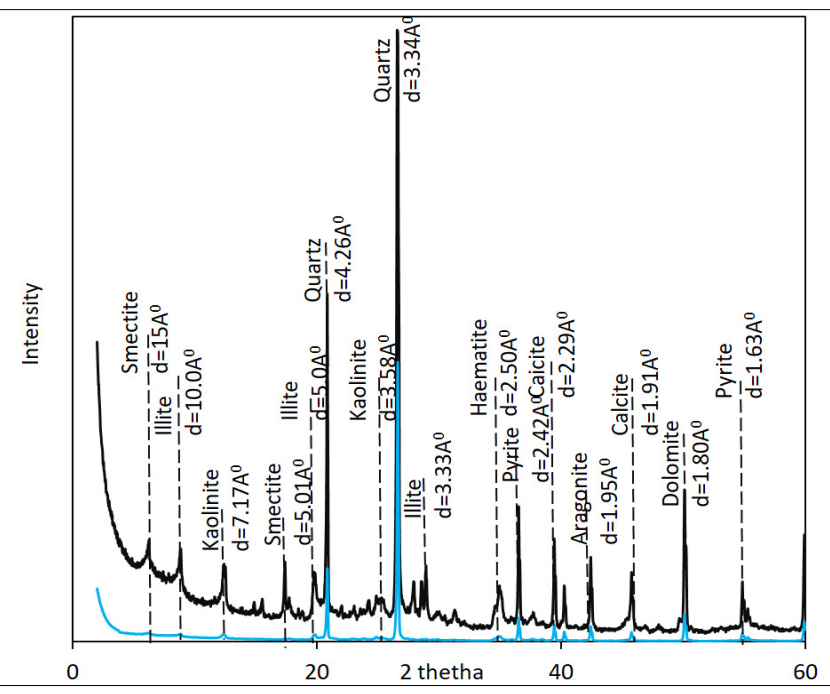

Figure 2. A representative XRD diffractogram for shales from Firehouse Creek (blue) and Seneca Quarry (Black respectively) 
EGME analysis (Table 1) reported TSA within the ranges of 6.29 to $90.01 \mathrm{~m}^{2} / \mathrm{g}$. The highest TSA of $90.01 \mathrm{~m}^{2} / \mathrm{g}$ was recorded in sample SM01. XSA ranged from $1.32 \mathrm{~m}^{2} / \mathrm{g}$ to $29.89 \mathrm{~m}^{2} / \mathrm{g}$ while ISA reported were from $4.98 \mathrm{~m}^{2} / \mathrm{g}$ to $64.62 \mathrm{~m}^{2} / \mathrm{g}$. The lowest XSA and ISA were reported in sample SM16 whilst the highest values of these two parameters were recorded in samples SM03 and SM04 respectively.

Table 1. Showing Sample Properties

\begin{tabular}{|c|c|c|c|c|c|c|}
\hline LOCAL & SID & XSA & TSA & ISA & TOC & E4/E6 \\
\hline \multirow{20}{*}{ 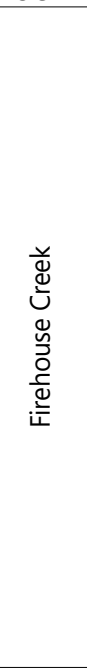 } & SM01 & 29.03 & 90.00 & 60.97 & 28.59 & 1.72 \\
\hline & SM02 & 28.86 & 77.61 & 48.76 & 25.13 & 1.54 \\
\hline & SM03 & 29.89 & 86.00 & 56.11 & 29.84 & 1.50 \\
\hline & SM04 & 21.38 & 86.00 & 64.62 & 24.46 & 1.45 \\
\hline & SM05 & 26.42 & 80.00 & 53.58 & 25.62 & 1.41 \\
\hline & SM06 & 8.29 & 26.41 & 18.13 & 11.19 & 1.00 \\
\hline & SM07 & 2.84 & 9.09 & 6.25 & 10.01 & 0.33 \\
\hline & SM08 & 15.40 & 27.20 & 11.80 & 13.02 & 0.98 \\
\hline & SM09 & 18.59 & 70.10 & 51.51 & 20.61 & 0.97 \\
\hline & SM10 & 14.41 & 32.16 & 17.75 & 11.55 & 0.97 \\
\hline & SM11 & 17.64 & 54.94 & 37.30 & 18.45 & 0.96 \\
\hline & SM12 & 15.02 & 31.47 & 16.45 & 12.98 & 0.91 \\
\hline & SM13 & 17.18 & 63.20 & 46.02 & 18.15 & 1.18 \\
\hline & SM14 & 4.10 & 15.02 & 10.92 & 10.02 & 0.16 \\
\hline & SM15 & 6.42 & 18.00 & 11.58 & 10.64 & 0.20 \\
\hline & SM16 & 1.32 & 6.29 & 4.98 & 8.03 & 0.09 \\
\hline & SM17 & 25.98 & 67.00 & 41.02 & 23.71 & 1.41 \\
\hline & SM18 & 15.40 & 47.22 & 31.82 & 15.01 & 1.01 \\
\hline & SM19 & 12.34 & 30.12 & 17.78 & 11.55 & 0.81 \\
\hline & SM20 & 12.22 & 30.55 & 18.33 & 13.02 & 0.98 \\
\hline \multirow{20}{*}{ 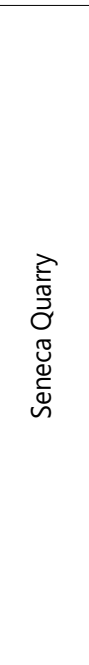 } & SQ01 & 1.31 & 21.3615 & 20.05 & 4.75 & 0.32 \\
\hline & SQ02 & 35.91 & 80.02 & 44.09 & 29.56 & 1.68 \\
\hline & SQ03 & 22.38 & 60.91 & 38.53 & 19.45 & 1.48 \\
\hline & SQ04 & 25.92 & 60.98 & 35.06 & 20.71 & 1.42 \\
\hline & SQ05 & 15.17 & 15.9 & 0.73 & 11.5 & 0.92 \\
\hline & SQ06 & 9.61 & 30.21 & 20.60 & 11.4 & 0.70 \\
\hline & SQ07 & 16.73 & 40.71 & 23.98 & 14.2 & 1.02 \\
\hline & SQ08 & 21.42 & 65.12 & 43.70 & 18.16 & 1.44 \\
\hline & SQ09 & 19.80 & 50.45 & 30.65 & 17.05 & 1.11 \\
\hline & SQ10 & 21.53 & 60.45 & 38.92 & 18.8 & 1.13 \\
\hline & SQ11 & 8.75 & 27.1 & 18.35 & 10.2 & 0.60 \\
\hline & SQ12 & 5.44 & 8.77 & 3.33 & 6.88 & 0.23 \\
\hline & SQ13 & 2.09 & 9.01 & 6.92 & 5.80 & 0.34 \\
\hline & SQ14 & 7.00 & 19.98 & 12.98 & 9.72 & 0.49 \\
\hline & SQ15 & 2.40 & 7.22 & 4.82 & 6.48 & 0.19 \\
\hline & SQ16 & 6.08 & 8.97 & 2.89 & 7.93 & 0.41 \\
\hline & SQ17 & 9.61 & 19.78 & 10.17 & 11.92 & 0.62 \\
\hline & SQ18 & 16.73 & 35.00 & 18.27 & 14.61 & 1.02 \\
\hline & SQ19 & 14.23 & 45.41 & 31.18 & 15.01 & 1.03 \\
\hline & SQ20 & 19.80 & 50.43 & 30.63 & 16.11 & 1.11 \\
\hline
\end{tabular}

TOC values range between 8.03 to $29.84 \%$. Sample SM16 and SM03 reported the least and highest TOC values respectively. An average of $16.14 \mathrm{~m}^{2} / \mathrm{g}, 47.42 \mathrm{~m}^{2} / \mathrm{g}, 31.28$ and $17.08 \%$ was recorded for XSA, TSA, ISA, and TOC respectively. The aromaticity (E4/E6) values in the samples from this locality range from 0.09 to 1.72 . About $45 \%$ of the studied samples were aromatic (i.e. E4:E6>1). All the remaining 55\% were dominated by aliphatic compounds. An average of 0.98 E4:E6 was assigned to the samples.

\section{Seneca Stone Quarry}

The clay mineralogy of shale from the Seneca Stone Quarry is similar to the samples from the firehouse creek (Figure 2).

TSA values range from $7.22 \mathrm{~m}^{2} / \mathrm{g}$ to $80.02 \mathrm{~m}^{2} / \mathrm{g}$. SQ02 reported the highest TSA values. The range of values recorded for XSA and ISA are $1.31 \mathrm{~m}^{2} / \mathrm{g}$ to $35.91 \mathrm{~m}^{2} / \mathrm{g}$ and $0.74 \mathrm{~m}^{2} / \mathrm{g}$ to $44.09 \mathrm{~m}^{2} / \mathrm{g}$ respectively for samples SQ01 to SQ20. The least recorded ISA and XSA values were from samples SQ05 and SQ01 respectively.
TOC values from the Seneca Stone Quarry samples range from $4.75 \%$ to $29.56 \%$ with an average of $13.51 \%$. SQ02 reported the highest value and SQ01 the least. E4:E6 values at this site range from 0.19 to 1.68 . About $50 \%$ of the samples were dominated by aliphatic hydrocarbons (i.e. E4/E6 < 1 ).

The presence of aromatic organic hydrocarbons in most of the studied shales is supported by the aromatic $\mathrm{C}=\mathrm{C}$ stretching and Aryl- $\mathrm{H}$ (C-H bending) functional groups at wavelengths of $1600 \mathrm{~cm}^{-1}$ and $900 \mathrm{~cm}^{-1}$ respectively indicated in the representative FTIR spectrum (Figure 5). The highintensity methyl functional groups $(\mathrm{CH} 3)$ at wavelengths of $2960 \mathrm{~cm}^{-1}$ and $2850 \mathrm{~cm}^{-1}$ are supporting evidence of the dominance of aliphatic organic carbons in the samples. These are presented in the representative FTIR spectrum for the aliphatic dominated shales (blue curve in Figure 5). Despite the similarities between the hydrocarbons functional groups recorded in the shale, great variations exist between the peak intensities. These variations may account for the differences the aromaticity recorded.

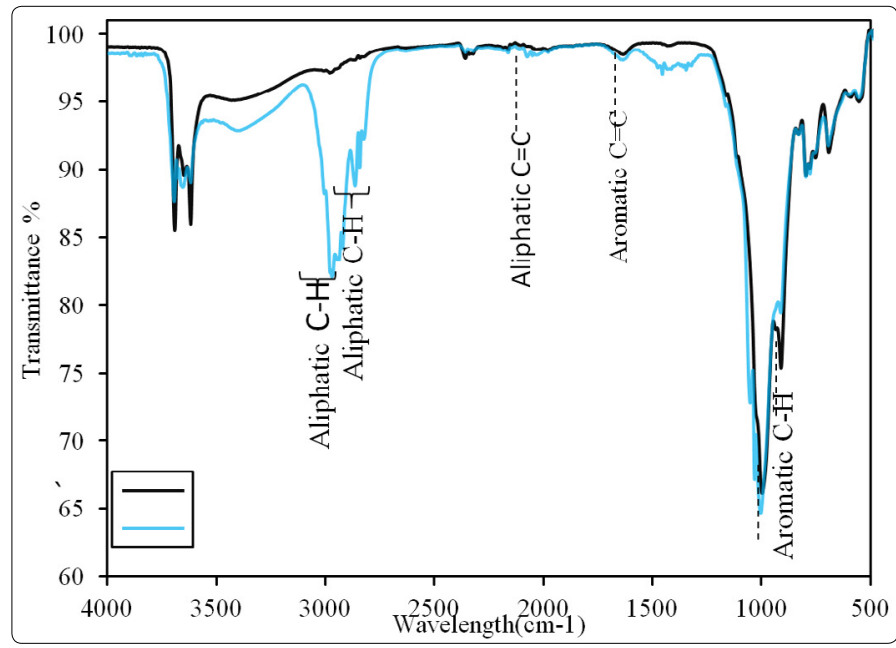

Figure 5. Representative FTIR Spectra Showing Organic Functional Groups the Samples

\section{Interpretation}

Variations in the SSA within the Bakoven Member may be accounted for by variations in clay mineralogy as well as OM type and content that make up the samples. The relatively high TSA and associated ISA values reported in most of the samples may be due to the presence of the 2:1 clay minerals like illite and smectites. These clay types have relatively large intracrystalline surface areas of about $750 \mathrm{~m}^{2} / \mathrm{g}$ [7] as such their presence in these samples explain the high reported TSA cum ISA values. Although higher values of ISA than these were expected.- Those recorded herein might have provided additional adsorptive sites (or micropore volume) increasing the samples EGME retention capacities [5] (Table 1). It is also likely the presence of other molecules compete for adsorption sites with the EGME molecules, presumably kaolinites and/or OM. This is because the accessibility of ISA to polar molecules according to Carter, et al. [3] is generally dependent on the relative adsorption forces of the introduced EGME molecules or ions to the clay mineral surfaces as compared to the attraction forces between adjacent clay molecules. 
Apart from mineralogy, variations in TOC may explain the variations in XSA, TSA and ISA recorded. The dominance of TOC accounted for the relatively high surface areas reported in the samples due to their provision of an excess site for molecule adsorption, others suggest that it is rather a relatively large specific surface that protects organic matter from microbial degradation [35-37]. Either way, these schools of thought suggest a close relationship between the dominance of organic matter and the creation of adsorptive site. Such relationship between TOC and surface area may throw more light on the relatively low XSA, TSA and ISA recorded in samples SM07, SM16, SQ15 and SQ16.

\section{The relationship between SSA and TOC}

The excellent positive correlations ( $R^{2}=0.91,0.92$ and 0.82 ) between SSA ( $\left.\mathrm{m}^{2} / \mathrm{g}\right)$ (XSA, TSA, ISA) and TOC (\%) distribution (Figure 6) was as expected and may suggest that the $\mathrm{OM}$ is bound to the inorganic surfaces; possibly the clays in the form of a monolayer coating the entire grain surfaces $[5,12,35,38,39]$ although Trask and Hammar [40] postulated that the two may be associated due to their hydrodynamic equivalence. The relatively lower positive correlation $\left(R^{2}=0.82\right)$ between TOC and ISA indicates that XSA of the samples are the main provider of additional adsorption capacity to OM for the samples.

Organic matter has been shown to increase SSA by providing additional sorptive sites in organic-rich shales through various mechanisms. For example, exchangeable cations in clay minerals may be replaced by anionic organic functional groups through interactions with the aluminol groups at relatively low pH (below the ZPC, when these functional groups carry a net positive charge [41]. Organic matter may also be adsorbed onto hydroxyl groups and electronegative atoms of adsorbing molecules through weak hydrogen bonds [42] or may intercalate between the intracrystalline layers of expansive clays through pathways such as cation exchange and/or dipole-dipole attractions where organic matter replaces interlayer water molecules [43]. They may also be simply associated with fine-grained sediments due to their hydrodynamic equivalence [40]. The adsorption of organic matter onto inorganic clay mineral surfaces indicated by the positive correlations confirms that clay minerals in the study areas protect organic matter from microbial activities and remineralization.

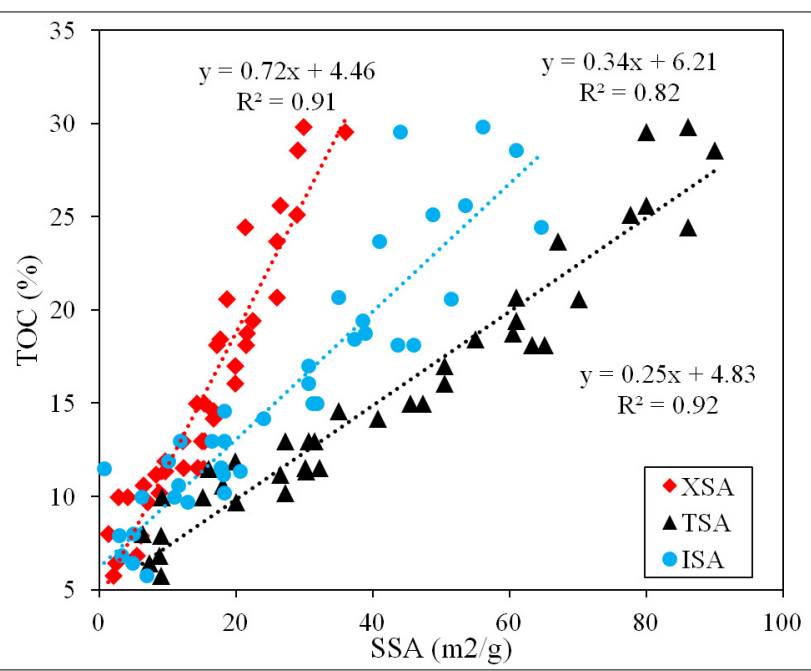

Figure 6. Relationship between TOC and SSA

\section{The relationship between SSA and Aromaticity}

Measured values of E4/E6 show a positive correlation $(\mathrm{R} 2=.0 .83,0.70,0.90)$ between the E4E6 hydrocarbon carbons $(\mathrm{E} 4 / \mathrm{E} 6<1)$ and SSA (TSA, ISA and XSA Figure 7). The positive correlation between E4/E6 $>1$ and TSA/XSA/ISA in most of the aromatic dominated shales may suggest the significance of the complexity of organic chemical structure, in particular, aromaticity in the SSA of the formation under investigation. These resultsare consistent with the works of $[9,44]$. Aromaticity of organic carbon has been shown to be relatively proportional to maturity $[45,46]$ which is also indirectly proportional to micropore volume [5] and subsequently to SSA. Aromatic hydrocarbons provide additional adsorptive sites increasing the specific surface areas of the respective shales. The details of the mechanisms for this in the shales in question, however, is not fully understood [44].

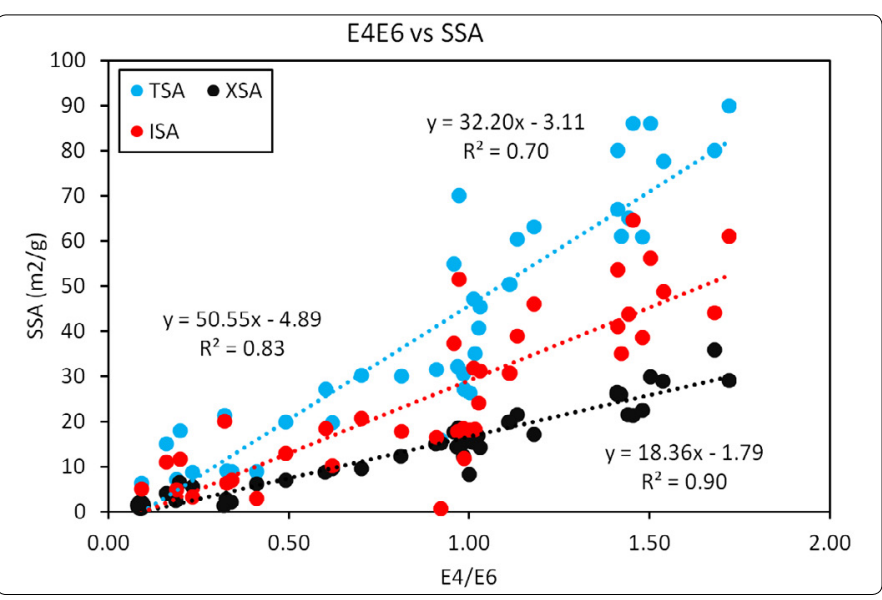

Figure 7. Relationship between E4:E6 and SSA

\section{Conclusion}

The study of the specific surfaces of shale samples from the Bakoven Member of the Union Spring Formation has shown that total, internal and external surface areas range from 6.29 to $90.01 \mathrm{~m} 2 / \mathrm{g}, 0.74$ to $64.62 \mathrm{~m} 2 / \mathrm{g}$ and $1.31 \mathrm{~m}^{2} / \mathrm{g}$ to $35.91 \mathrm{~m}^{2} / \mathrm{g}$ respectively. The primary variants of specific surfaces were organic matter content, aromaticity and clay mineralogy. All three parameters of SSA (i.e. TSA, ISA and XSA) follow linear trends with TOC although significant deviations from this trend are observed for individual samples. The complexities of the hydrocarbons also influence SSA positively though the mechanisms of their occurrence is poorly understood and thus requires further studies. The influence of mineralogy on SSA was ascribed to their clay contents. Although their exact influence may be known after quantitative clay mineralogical analysis.

\section{References}

1. Bingham JM, Golden DC, Buol SW, Weed SB, Bowen LH. Iron oxide mineralogy of well-drained Ultosols and ' ${ }^{\circ}$ sisals: $\mathrm{H}$. Influence on color, surface area and phosphate retention. Soil Science Association of America Journal. 1978; 42: 825-830.

2. Love FDE, Padmanabhan E, Gámez Vintaned JAG. Variations in specific surface area of some Oligocene Miocene shales. J Sci Research and Devel. 2016; 3(7): 33-43. 
3. Carter DL, Heilman MD, Gonzalez CL. Ethylene glycol monoethyl ether for determining surface area of silicate minerals. Soil Sci. 1965; 100: 356-360.

4. Delle SA. Factors affecting sorption of organic compounds in natural sorbent/ water systems and sorption coefficients for selected pollutants. A review. J Phys and Chem Reference Data. 2001; 30: 187-439. doi: 10.1063/1.1347984

5. Gasparik M, Bertier P, Gensterblum Y, Ghanizadeh A, Krooss BM, Littke R. Geological controls on the methane storage capacity in organic-rich shales. Intern J Coal Geol. 2014; 123, 34-51. doi: 10.1016/j.coal.2013.06.010

6. Porter L. Relationship between the retention of 2-ethoxyethanol by sodium-saturated clays and the retention of dioxane, tetrahydrofuran, and 2-methoxyethanol. Soil Science. 1971; 12: 156-160.

7. Van Olphen H, Fripiat JJ. Data Handbook for clay materials and other NonMetallic Minerals. New York: Pergamon Press. 1979.

8. Lu XC, Li FC, Watson AT. Adsorption studies of natural gas storage in devonian shales. Soci of Petroleum Engineers. 1995; 1-15. doi: 10.2118/26632PA

9. Ji L, Zhang T, Milliken KL, Qu J, Zhang X. Experimental investigation of main controls to methane adsorption in clay-rich rocks. Applied Geochemistry. 2012; 27(12): 2533-2545. doi: 10.1016/j.apgeochem.2012.08.027

10. Ross DJK, Bustin MR. The importance of shale composition and pore structure upon gas storage potential of shale gas reservoirs. Marine and Petroleum Geology. 2009; 26: 916-927. doi: 10.1016/j.marpetgeo.2008.06.004

11. Cerato $A B$, Lutenegger $A J$. Determination of surface area of fine-grained soils by the ethylene glycol monoethyl ether (egme) method. Geotechnical Testing Journal. 2002; 25. doi: 10.1520/GTJ11087J

12. Heister K. The measurement of the specific surface area of soils by gas and polar liquid adsorption methods-Limitations and potentials. Geoderma. 2014; 216: 75-87. doi: 10.1016/j.geoderma.2013.10.015

13. M. S. G. Producers, Oil \& Natural Gas Technology. 2010.

14. van Staal $C R$, Whalen JB, Vaquero PV, Zagorevski A, Rogers N. Precarboniferous, episodic accretion-related, orogenesis along the laurentian margin of the northern appalachians. In Anciemt orogens and moedrn analogus. 327, Murphy JB, Keppie JD, Hynes AJ, Editon. London: Geological Society Special Publication. 2009; 271-316.

15. Warner NR, Jackson RB, Darrah $T H$, et al. Geochemical evidence for possible natural migration of Marcellus Formation brine to shallow aquifers in Pennsylvania. Proc Nat Acad of Sci. 2012; 109: 11961-11966. doi: 10.1073/pnas.1121181109

16. Ettensohn FR. The Catskill delta complex and the Acadian orogeny: A model. Geological Society of America Special Papers. 1985; 201: 39-50. doi: 10.1130/SPE201-p39

17. Castle JW. Appalachian basin stratigraphic response to convergentmargin structural evolution. Basin Research. 2001; 13: 397-418. doi: 10.1046/j.0950-091x.2001.00157.x

18. Clarke JM. Classification of New York Series of geologic formations: New York State Museum, 1903.

19. Johnson JG, Klapper G, Sandberg CA. Devonian eustatic fluctuations in Euramerica. Geological Society of America Bulletin. 1985; 96: 567-587. doi: 10.1130/0016-7606

20. ver Straeten CA, Brett CE. Pragian to Eifelian strata (middle Lower to lower Middle Devonian), northern Appalachian Basin; stratigraphic nomenclatural changes: Northeastern. Geology and Environmental Sciences. 2006; 28: 80-95.

21. Danielsen EM, Over DJ, Baird GC, Ver Straeten. The Marcellus subgroup in the type area, central New York State. Stratigraphy. 2016; 13(3): 155-162.

22. Conptom AH, Allison SK. X-ray in Theory and Experiment. New York: Van Nostrand, 1935. doi: 10.1148/25.5.640

23. Suryanarayana $C$, Norton MG. X-ray diffraction: a practical approach: Springer Science \& Business Media, 2013.

24. Klug HP, Alexander LE. X-Ray Diffraction Procedures: For Polycrystalline and Amorphous Materials. $2^{\text {nd }}$ Edition. Wiley. 1974, 992.

25. Moore DM, Reynolds RC. X-ray Diffraction and the Identification and Analysis of Clay Minerals. Oxford university press. 1989.

Int J Petrochem Res.

Volume 2 • Issue $3 \cdot 1000140$ clays: powder X-ray diffraction analyses. Clays and Clay Minerals. 2001; 49(5): 398-409.

27. Quirk JP. Significance of surface areas calculated from water vapour sorption isotherms by the use of BET Equation. Soil science. 1955; 80(6): 433-430. doi: 10.1097/00010694-195512000-00001

28. Carter D, Mortland M, Kemper W. Specific Surface in A. Klute-Methods of Soil Analysis. $2^{\text {nd }}$ Edition. 1960; 413-423.

29. Dow WG, Pearson DB. Organic Matter In Gulf Coast Sediments. Offshore Technology Conference. 1975. doi: 10.4043/2343-MS

30. Schnitzer $M$, Neyroud JA. Further investigations on the chemistry of fungal "humic acids". Soil Biology and Biochemistry. 1975; 7(6): 365-371. doi: 10.1016/0038-0717(75)90051-6

31. Stevenson FJ. Humus chemistry; genesis, composition, reactions. $2^{\text {nd }}$ Edition. 1982.

32. Ramli MS, Padmanabhan E. Heterogeneity of the hydrocarbon distribution in tertiary sediments of north-east Sarawak. International Petroleum Technology Conference. Thailand, 2011. doi: 10.2523/IPTC-14553-MS

33. Coates J. Interpretation of Infrared Spectra, A Practical Approach. Encyclopedia of Analytical Chemistry. R. A. Meyers, Edition, ed Chichester UK: John Wiley \& Sons, Ltd. 2000; 12: 10815-10837. doi: 10.1002/9780470027318

34. Stuart BH. Infrared Spectroscopy: Fundamentals and Applications. Wiley. 2005.

35. Hedges Jl, Keil RG. Sedimentary organic matter preservation: an assessment and speculative synthesis. Marine Chemistry. 1995; 49(2-3): 81-115. doi: 10.1016/0304-4203(95)00008-F

36. Mayer LM. Surface area control of organic carbon accumulation in continental shelf sediments. Geochimica et Cosmochimica Acta. 1994;

37. Mayer LM. Relationships between mineral surfaces and organic carbon 347-363. doi: 10.1016/0009-2541(94)90063-9

38. Saidian $M$, Godinez $\amalg$, Prasad M. Effect of clay and organic matter on nitrogen adsorption specific surface area and cation exchange capacity in shales (mudrocks). Journal of Natural Gas Science and Engineering. 2015; 33: 1095-1106. doi: 10.1016/j.jngse.2016.05.064

39. Tang HM, Wang JJ, Zhang $\mathrm{LH}$, et al. Testing method and controlling factors of specific surface area of shales. Journal of Petroleum Science and Engineering. 2016; 143: 1-7. doi: 10.1016/j.petrol.2016.02.009

40. Trask PD, Hammar HE. Organic Content of Recent Marine Sediments. AAPG. 1934.

41. Roychand $P$, Angove $M$, Tisdall J. Sorptive Protection of Organic Matter in Soil. World Congress of Soil Science. 2010; 19: 235-238.

42. Kubicki JD, Schroeter LM, Itoh MJ, Nguyen BN, Apitz SE. Attenuated total reflectance fourier transform infrared spectroscopy of carboxylic acids adsorbed into mineral surfaces. Geochimica et Cosmochimica Acta. 1999; 63(18): 2709-2725. doi: 10.1016/S0016-7037(99)00194-5

43. Schnitzer M. Binding of Humic Substances by Soil Mineral Colloids. Interactions of Soil Minerals with Natural Organics and Microbes. 1966; 17: 77-102.

44. Zhang T, Ellis GS, Ruppel SC, Milliken K, Yang R. Effect of organic-matter type and thermal maturity on methane adsorption in shale-gas systems. Organic Geochemistry. 2012; 47: 120-131. doi: 10.1016/j.orggeochem.2012.03.012

45. Bernard S, Wirth R, Schreiber A, Schulz HM, Horsfield B. Formation of Shale (Fort Worth Basin). International Journal of Coal Geology. 2012; 103: 3-11. doi: 10.1016/j.coal.2012.04.010

46. Bernard S, Horsfield B, Schulz HM, Wirth R, Schreiber A, Sherwood N Geochemical evolution of organic-rich shales with increasing maturity: A STXM and TEM study of the Posidonia Shale (Lower Toarcian, northern Germany). Marine and Petroleum Geology. 2012; 31(1): 70-89. doi: 10.1016/j.marpetgeo.2011.05.010
26. Chipera SJ, Bish DL. Baseline studies of the clay minerals society source 58(4): 1271-1284. doi: 10.1016/0016-7037(94)90381-6 concentrations in soils and sediments. Chemical Geology. 1994; 114(3-4): nanoporous pyrobitumen residues during maturation of the Barnett 